\title{
ChemComm
}

Volume 57

Number 45

7 June 2021

Pages 5473-5598

Chemical Communications

rsc.li/chemcomm

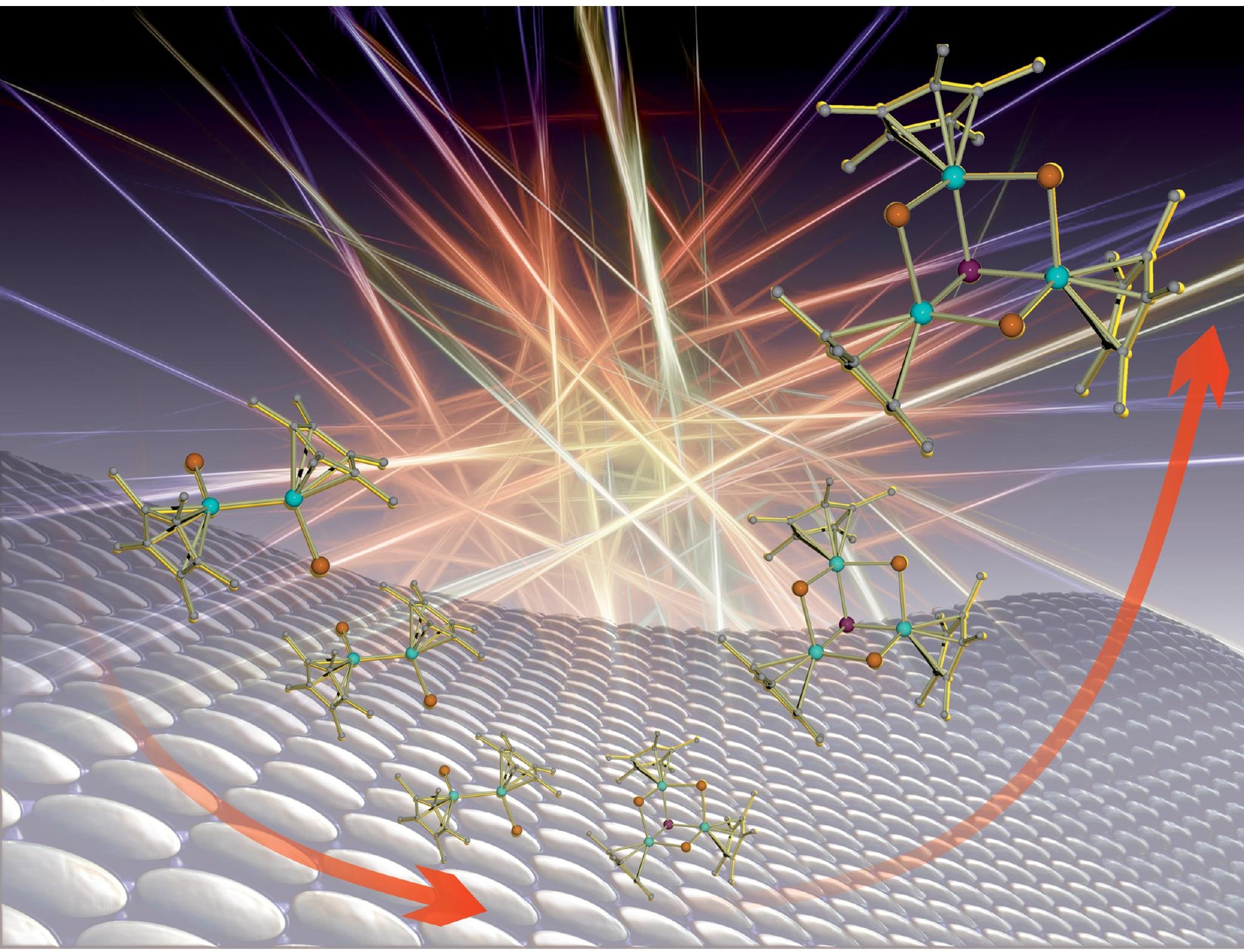

ISSN 1359-7345 
Check for updates

Cite this: Chem. Commun., 2021, 57,5503

Received 18th March 2021,

Accepted 6th May 2021

DOI: $10.1039 / \mathrm{d} 1 \mathrm{cc} 01475 \mathrm{~g}$

rsc.li/chemcomm

\section{Reactivity of mono- and divalent aluminium compounds towards group 15 nanoparticles $\dagger$}

\author{
Adrian Hauser, (D) Luca Münzfeld (D) and Peter W. Roesky (D) *
}

\begin{abstract}
Herein, we present a novel approach towards organometallic group 13/15-compounds, i.e. the reaction of nanoparticular arsenic and antimony with low-valent aluminium species. The reaction of the two-electron reducing agent $\left[\mathrm{AlCp}^{*}\right]_{4}\left(\mathrm{Cp}^{*}=\mathrm{C}_{5} \mathrm{Me}_{5}\right)$ with arsenic nanoparticles gave rise to a mixture of two unprecedented decaand dodecanuclear Al-As clusters. In contrast, the analogous transformation with nanoparticular antimony yielded the already known Al-Sb compound [( $\left.\mathrm{AlCp})_{3} \mathrm{Sb}_{2}\right]$. Additionally, two different dialanes $[A I C p * X]_{2}(X=B r, I)$ were employed as one-electron reducing agents, forming calix like coordination compounds upon reaction with nano arsenic. The isolated species significantly enlarge the accessible structural variety of molecular group 13/15 compounds, highlighting the exceptional utility and reactivity of nanoscale group 15 precursors.
\end{abstract}

Low-valent organometallic compounds of aluminium have been known for several decades. Textbook examples are the mono valent compounds $\left[\mathrm{AlCp}^{*}\right]_{4}$ (Chart 1 , left $)\left(\mathrm{Cp}^{*}=\mathrm{C}_{5} \mathrm{Me}_{5}\right)$, and $\left[\mathrm{Al}\left({ }^{\mathrm{Dipp}} \mathrm{BDI}\right)\right]\left({ }^{\mathrm{Dipp}} \mathrm{BDI}=\right.$ diisopropylphenyl- $\beta$-diketiminate $),{ }^{1}$ which were studied intensively. ${ }^{2}$ Very recently, the reactivity of $\left[\mathrm{Al}\left({ }^{\text {Dipp }} \mathrm{BDI}\right)\right]$ was enhanced by deprotonating one methyl group in the ligand backbone to obtain the corresponding aluminylanion. ${ }^{3}$ However, the first anionic $\mathrm{Al}(\mathrm{I})$ complex exhibiting a unique reactivity was reported shortly before, establishing a new generation of $\mathrm{Al}(\mathrm{I})$-compounds. ${ }^{4}$ These recent advances in the synthetic chemistry of molecular Al(I)-species, as well as in depth reactivity studies, have brought low-valent group 13 compounds back to the spotlight of main group organometallic chemistry. ${ }^{5}$ Besides above mentioned monovalent aluminium(I) compounds, isolable divalent aluminium compounds are well-established. ${ }^{4 a, 6}$ One example is $\left[\mathrm{AlCp}^{*} \mathrm{X}\right]_{2}(\mathrm{X}=\mathrm{Br}, \mathrm{I})$ (Chart 1, right), which can be isolated as an intermediate from

Institute of Inorganic Chemistry, Karlsruhe Institute of Technology (KIT), Engesserstraße 15, Karlsruhe D-76131, Germany.E-mail: roesky@kit.edu $\dagger$ Electronic supplementary information (ESI) available: Experimental and crystallographic details. CCDC 2071388-2071391. For ESI and crystallographic data in CIF or other electronic format see DOI: 10.1039/d1cc01475g the synthesis of $\left[\mathrm{AlCp}^{*}\right]_{4}$ by the reduction of $\left[\mathrm{AlCp}^{*} \mathrm{X}(\mu-\mathrm{X})\right]_{2}$ with sodium or potassium. Due to their tendency to disproportionate easily, these dialanes have only been used sporadically in dialumination reactions of organic substrates or simple oxidation reactions so far. ${ }^{7}$

In contrast, $\left[\mathrm{AlCp}^{*}\right]_{4}$ has been reacted with a large number of organic substrates and main group elements. ${ }^{2 i, 5 d, 8}$ Thus, the aluminium group 16 heterocubanes $\left[\mathrm{Cp}^{*} \mathrm{AlE}\right]_{4}(\mathrm{E}=\mathrm{O}, \mathrm{S}, \mathrm{Se}, \mathrm{Te})$ (Chart 2, left) can be obtained by reaction of $\left[\mathrm{AlCp}^{*}\right]_{4}$ with the corresponding group 16 elements. ${ }^{9,10}$ Similarly, $\left[\mathrm{AlCp}^{*}\right]_{4}$ reacts with white phosphorus resulting in $\left[\mathrm{P}_{4}\left(\mathrm{Cp}^{*} \mathrm{Al}\right)_{6}\right]$ (Chart 2, centre), which consists of a $\mathrm{P}_{4} \mathrm{Al}_{6}$ cage. ${ }^{11}$ In contrast, no reaction has been reported of an $\mathrm{Al}(\mathrm{I})$ species with the heavier group 15 elements $\mathrm{As}, \mathrm{Sb}, \mathrm{Bi}$.

The corresponding derivatives $\left[\mathrm{Pn}_{2}\left(\mathrm{AlCp}^{*}\right)_{3}\right](\mathrm{Pn}=\mathrm{As}, \mathrm{Sb}, \mathrm{Bi})$ (Chart 2, right) can only be obtained by reaction of $\left[\mathrm{AlCp}^{*}\right]_{4}$ with organometallic precursors as arsenic, antimony and bismuth source since the direct reaction with the elements was not observed. ${ }^{12}$ Recently, we reported on elemental arsenic $\left(\mathrm{As}^{0}{ }_{(\text {nano })}\right)$ and antimony $\left(\mathrm{Sb}^{0}{ }_{(\text {nano })}\right)$ nanoparticles, which react with samarocene as highly reactive elemental group 15 precursors. ${ }^{13}$ Herein, we showcase that this concept can be extended to low-valent main group chemistry. Due to the drastically increased surface-to-volume ratio compared to often unreactive bulk material the nanoparticles used in this work exhibit increased reactivity. ${ }^{14}$ In addition, compared to
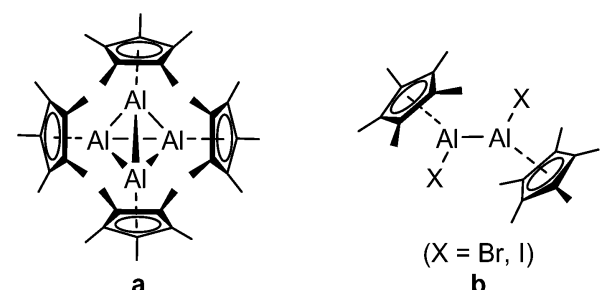

Chart 1 Classes of low-valent aluminium compounds of relevance to this work: (a) $\mathrm{Al}(\mathrm{I})$-tetramer $\left[\mathrm{AlCp}^{*}\right]_{4}$ (left) and (b) $\mathrm{Cp}^{*}$-containing dialanes $[A I C p * X]_{2}(X=B r, I)$ (right). 


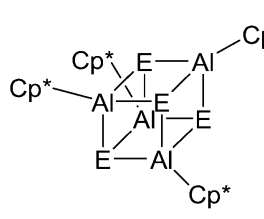

$$
\mathrm{Cp}^{*}=\mathrm{O}, \mathrm{S}, \mathrm{Se}, \mathrm{Te}
$$

Chart 2 Products from the reaction of $\left[\mathrm{AlCp}^{*}\right]_{4}$ with (a) elements of group 16 (left) (b) white phosphorus (centre) and (c) group 15 organyls (right).

yellow arsenic $\left(\mathrm{As}_{4}\right)$, which is highly photosensitive and rapidly decomposes to the thermodynamically more stable grey arsenic, ${ }^{15} \mathrm{As}^{0}{ }_{\text {(nano) }}$ as well as $\mathrm{Sb}_{\text {(nano) }}^{0}$ are employable in redox-chemistry, while being readily storable and handleable.

Herein, we report the reactivity of nanoparticular arsenic and antimony towards $\left[\mathrm{AlCp}^{*}\right]_{4}$, which led to the formation of new aluminium-arsenic compounds exhibiting unexpected structural motifs, as well as a reported aluminium-antimony compound. Furthermore, we used the divalent aluminium species $\left[\mathrm{AlCp}^{*} \mathrm{X}\right]_{2}(\mathrm{X}=\mathrm{Br}, \mathrm{I})$ for the first time in a purely inorganic transformation as a one-electron reducing agent.

The reaction of $\left[\mathrm{AlCp}^{*}\right]_{4}$ with an excess of arsenic nanoparticles at $70{ }^{\circ} \mathrm{C}$ in toluene for several days resulted in two different compounds. Despite several attempts and variation of the reaction conditions as well as the stoichiometry, $\left[\left(\mathrm{Cp}^{*} \mathrm{Al}_{6} \mathrm{As}_{4}\right](\mathbf{1})\right.$ and $\left[\left(\mathrm{Cp}^{*} \mathrm{Al}\right)_{6} \mathrm{As}_{5} \mathrm{Al}\right](2)$ were only obtainable as a mixture of yellow (1) and red crystals (2) (Scheme 1). Additionally, the similar solubility of both species in common organic solvents prevented fractional crystallization. Nevertheless, both compounds could be characterised by manually separating the crystalline products. During the formation of compound $\mathbf{1}$, formally one and a half $\left[\mathrm{AlCp}^{*}\right]_{4}$ moieties are reacting with arsenic nanoparticles. The aluminium atoms are oxidized to give six $\left[\mathrm{Al}^{\mathrm{III}}\right]$-centres, each capped by one $\mathrm{Cp}^{*}$-ligand. The respective As atoms are present in oxidation state -3 building up an $\mathrm{As}_{4} \mathrm{Al}_{6}$ cage structure, which is known for the lighter phosphorus congener. ${ }^{11}$

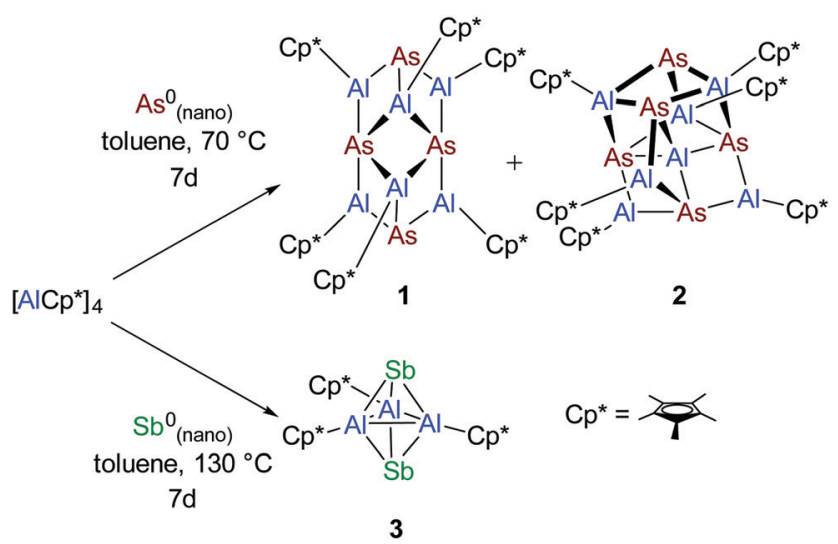

Scheme 1 Reactivity of $\left[\mathrm{AlCp}^{\star}\right]_{4}$ towards group 15 nanoparticles ( $\mathrm{As}^{0}$ (nano) and $\mathrm{Sb}_{(\text {nano) }}^{0}$.
Fig. 1 (left) shows the molecular structure of compound 1 in the solid state. The $\mathrm{As}_{4} \mathrm{Al}_{6}$ framework can be described by two face-sharing $\mathrm{Al}_{4} \mathrm{As}_{4}$ cubes, each missing one arsenic atom on the opposite corners. Formally, 1 can be considered as fusion of two $\left[\left(\mathrm{AlCp}^{*}\right)_{3} \mathrm{As}_{2}\right]^{16}$ molecules. The four outer $\mathrm{Al} 1$ atoms are each bearing a $\mathrm{Cp}^{*}$-ligand in a $\eta^{5}$-coordination mode with an Al1- $\mathrm{Ct}_{\mathrm{Cp}^{*}}\left(\mathrm{Ct}_{\mathrm{Cp}^{*}}=\right.$ centroid of the $\mathrm{Cp}^{*}$ moiety $)$ distance of 1.9066(8) A, while the inner two Al2 atoms are only $\eta^{1}$-coordinated by their corresponding $\mathrm{Cp}^{*}$-ligands with an Al2-C bond length of 2.067(3) A. The bond lengths of the Al-As bonds vary from 2.4186(7) $\AA$ for Al1-As2 to 2.5019(6) $\AA$ for Al2-As1, which is within the expected range of comparable compounds with Al-As single bonds. ${ }^{16,17}$ As expected, the Al-As bonds are longer compared to the Al-P bonds of the isostructural phosphorus compound, while the $\mathrm{Al}-\mathrm{C}$ distances are consistent with reported ones. ${ }^{11}$

As mentioned above, another type of crystals obtained from the same reaction of $\left[\mathrm{AlCp}^{*}\right]_{4}$ with $\mathrm{As}^{0}{ }_{\text {(nano) }}$ could be characterised. This revealed the formation of another, previously unknown aluminium arsenic cage complex (Fig. 1, right). As illustrated in Fig. 1, compound 2 consists of an $\mathrm{As}_{5} \mathrm{Al}_{7}$ cage, which can be described as two distorted face-sharing cubes lacking only one arsenic atom at one corner. In addition, the arsenic atoms As1 and As2 are four-fold coordinated and bridged by one more aluminium atom $(\mathrm{Al} 2)$. All other As atoms are three-fold coordinated by aluminium atoms, which are all in a trivalent oxidation state. For $\mathrm{Al} 2, \mathrm{Al} 3$, and $\mathrm{Al} 4$ the $\mathrm{Cp}^{*}$-ligands are $\eta^{5}$-coordinated $\left(\mathrm{Al} 2-\mathrm{Ct}_{\mathrm{Cp}^{*}} 1.896(2) \AA\right.$, $\mathrm{Al} 3-\mathrm{Ct}_{\mathrm{Cp}^{*}}$

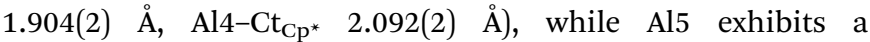
$\eta^{3}$-coordination mode $\left(\mathrm{Al} 1-\mathrm{Ct}_{\mathrm{Cp}^{*}} 2.360(2) \AA\right)$ of the five membered ring. In contrast, the central aluminium atom (Al1) is not bound to a $\mathrm{Cp}^{*}$-ligand. Instead, Al1 is exclusively tetrahedrally coordinated by four arsenic atoms. The average Al1-As bond length is $2.4647 \AA$, which is comparable to values observed in compound 1 and further Al-As single bonds known from literature. ${ }^{16-18}$ The other $\mathrm{Al}-\mathrm{As}$ bonds in compound 2 are in a similar range.

After the successful reduction of $\mathrm{As}^{0}{ }_{\text {(nano) }}$ with $\left[\mathrm{AlCp}^{*}\right]_{4}$, we decided to examine the reactivity towards $\mathrm{Sb}^{0}{ }_{(\text {nano). }}$. Actually, we isolated the already reported compound $\left[\left(\mathrm{AlCp}^{*}\right)_{3} \mathrm{Sb}_{2}\right]$ (3)
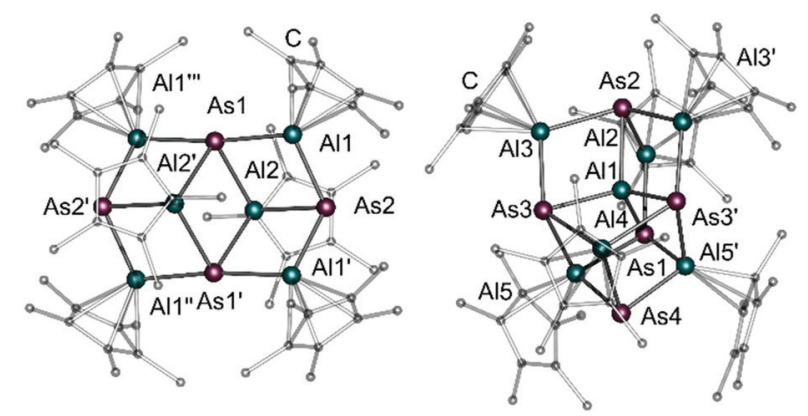

Fig. 1 Molecular structure of compound 1 (left) and compound 2 (right) in the solid state. For better clarity: hydrogen atoms are omitted and $\mathrm{Cp}^{*}$ ligands are transparent. Color code: As (dark red), Al (light blue), C (transparent black). 
(Scheme 1) instead of a compound isostructural to 1 or 2 . The formation of compound 3 was confirmed by X-ray diffraction and NMR studies. In the ${ }^{1} \mathrm{H}$ NMR, the resonance for the $\mathrm{Cp}^{*}$ methyl protons was observed at $\delta=2.08 \mathrm{ppm}$ while in the ${ }^{13} \mathrm{C}\left\{{ }^{1} \mathrm{H}\right\}$ NMR two resonances, one for the methyl carbon at $\delta=12.0 \mathrm{ppm}$ and one for the ring carbon at $\delta=116.1 \mathrm{ppm}$ were detected, which is consistent with the literature. ${ }^{12 a, 12 c}$ However, we could show once again, that $\mathrm{Sb}^{0}$ (nano) is a highly reactive source for elemental antinomy to form organometallic compounds, which are not accessible from bulk antimony. ${ }^{12 a}$

Our next challenge consisted in studying the reactivity of the nanoparticles towards $\mathrm{Al}(\mathrm{II})$-species. In contrast to $\left[\mathrm{AlCp}^{*}\right]_{4}$, these species usually act as a one-electron reducing agent. As reactive precursor we used the dialanes $\left[\mathrm{AlCp}^{*} \mathrm{X}\right]_{2}(\mathrm{X}=\mathrm{Br}, \mathrm{I})$ (Chart 1). By using two different halogens we had the opportunity to study the influence of the substituents on the reactivity. ${ }^{19}$ For both species a reaction with arsenic nanoparticles was observed after stirring the reaction mixture in toluene at $80{ }^{\circ} \mathrm{C}$ for four days, yielding $\left[\left(\mathrm{Cp}^{*} \mathrm{AlBr}\right)_{3} \mathrm{As}\right](4)$ and $\left[\left(\mathrm{Cp}^{*} \mathrm{AlI}\right)_{3} \mathrm{As}\right](5)$ (Scheme 2). These reactions are, to the best of our knowledge, the first purely inorganic transformations of this type of dialanes. Formally, elemental As is triply reduced to $\left[\mathrm{As}^{-\mathrm{III}}\right]$ upon reaction, while the $\left[\mathrm{Al}^{\mathrm{II}}\right]$ atoms are oxidized to $\left[\mathrm{Al}^{\mathrm{III}}\right]$. During this process the $\mathrm{Al}-\mathrm{Al}$ bond is cleaved. The observed differences in the yields $(4=51 \% ; 5=29 \%$ ) could stem from the less stable Al-Al bond in the iodine compound, which could favor some unidentified side reactions. ${ }^{19}$ In con-

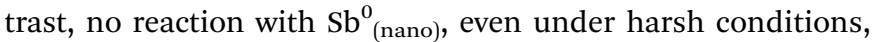
was observed, indicating a slightly lower reactivity compared to $\mathrm{As}^{0}{ }_{(\text {nano) }}$.

As shown in Fig. 2, compound 4 exhibits a calix-like structural motif with an $\left[\mathrm{As}^{-\mathrm{III}}\right]$ centre, bonded to three $\left[\mathrm{Al}^{\mathrm{III}} \mathrm{Cp}^{*}\right]$ units, which in turn are bridged to the adjacent aluminium atoms via one bromine atom each. Every $\left[\mathrm{Al}^{\mathrm{III}}\right]$ centre is capped by a $\eta^{5}$-coordinated $\mathrm{Cp}^{*}$-ligand with an average $\mathrm{Al}-\mathrm{Ct}_{\mathrm{Cp}^{*}}$ distance of $1.9367 \AA$. The As1-Al bond lengths vary from 2.4118(13)

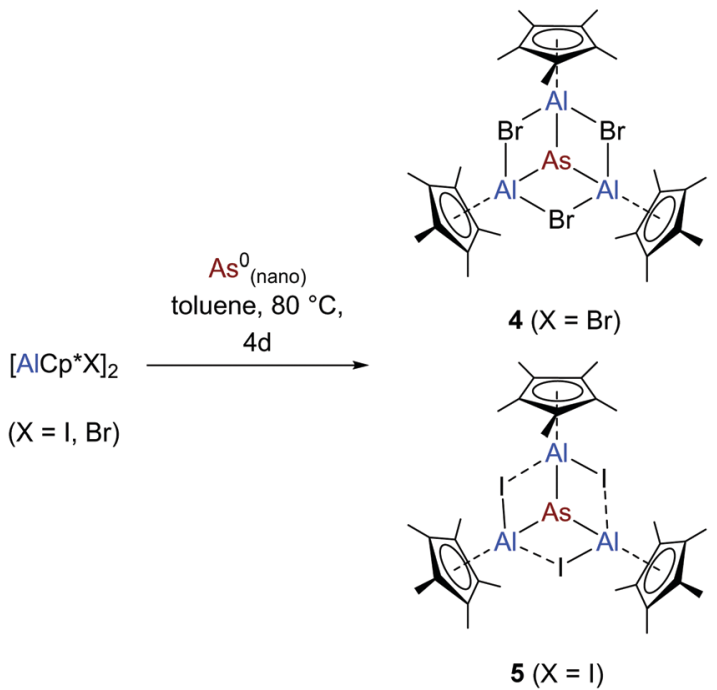

Scheme 2 Reactivity of the dialanes $[A I C p * X]_{2}(X=B r, I)$ towards $A s^{0}{ }_{(\text {nano) }}$.
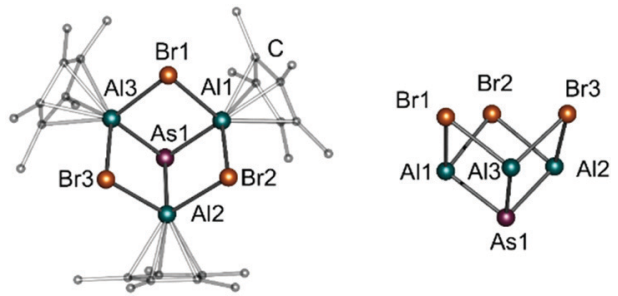

Fig. 2 Molecular structure of compound $\mathbf{4}$ in the solid state (left) and side view of the calix-like core structure (right). For better clarity: hydrogen atoms are omitted and $\mathrm{Cp}^{\star}$-ligands are transparent. Color code: As (dark red), Al (light blue), $\mathrm{Br}$ (orange), C (transparent black).

to $2.4374(12) \AA$, which is consistent with previously reported compounds. $^{16-18}$ As expected, the bond lengths for the bridging bromine atoms (e.g. Al1-Br2 2.5569(13) $\AA$ and $\mathrm{Al} 2-\mathrm{Br} 2$ 2.6091(13) $\AA$ ) are slightly longer than for terminal $\mathrm{Al}-\mathrm{Br}$ bonds $(2.31 \AA-2.41 \AA)$ and in the same range as other $\mathrm{Al}-\mathrm{Br}$ bond lengths in a bridging bonding mode (e.g. $2.513 \AA-2.516 \AA) .{ }^{2 h, 7 c, 20}$ The calix-like structure with an opening angle (angle between $\mathrm{Al} 1-\mathrm{Al} 2-\mathrm{Al} 3$ plane and As1-Al1$\mathrm{Al} 3-\mathrm{Br} 1$ plane, Fig. S19, ESI $\dagger$ ) of $124.12^{\circ}$, is the result of the trigonal pyramidal coordination of the central As atom (As1). The As-Al-Br angles are between 95.79 $(4)^{\circ}$ and 98.33(5) .

In the solid state, compound 5 (Fig. 3) forms a calix-like structure similar to compound $\mathbf{4}$ with an opening angle of $125.59^{\circ}$ (angle between Al1-Al1'-Al1" plane and As1-Al1-Al1'-I1 plane, Fig. S21, ESI $\dagger$ ). However, the bonding situation of the halide is different. While the Al1-I1 distance (2.706(2) $\AA$ ) is in the range of $\mathrm{Al}-\mathrm{I}$ single bonds, ${ }^{7 a}$ the $\mathrm{Al1}{ }^{\prime}-\mathrm{I} 1$ distance (3.088(2) $\AA$ ) is beyond these values. However, it is still shorter than the sums of the van der Waals radii. ${ }^{21}$ Therefore, a weak interaction may occur (shown as dashed lines in Scheme 2 and Fig. 3), which results in an asymmetrically bridged Al-halide bond. Compared to compound 4, the As-Al-X (X = I) angle $\left(102.29(5)^{\circ}\right)$ is wider, which can be explained by the asymmetrically, rather than symmetrically bridged, Al-halide bonding situation. The Al1-C distances in $\mathbf{5}$ are

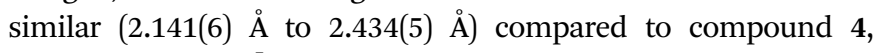
resulting in a $\eta^{5}$-coordination of the $\mathrm{Cp}^{*}$-ligand $\left(\mathrm{Al} 1-\mathrm{Ct}_{\mathrm{Cp}^{*}}\right.$

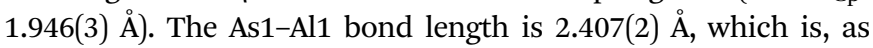
expected, in the same range as for compounds 1, 2 and 4.

In summary, we investigated the reactivity of $\mathrm{Al}(\mathrm{I})$ - and $\mathrm{Al}(\mathrm{II})-$ compounds towards elemental As and $\mathrm{Sb}$ nanoparticles. By
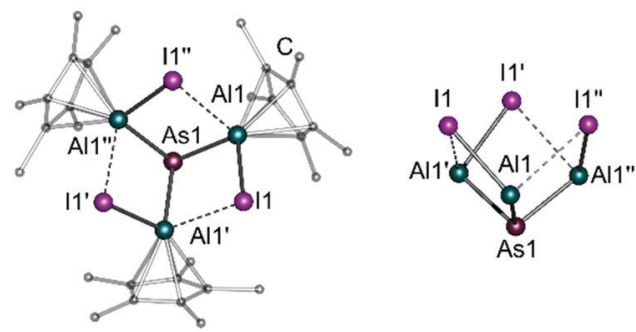

Fig. 3 Molecular structure of compound $\mathbf{5}$ in the solid state (left) and side view of the calix-like core structure (right). For better clarity: hydrogen atoms are omitted and $\mathrm{C}^{*}$-ligands are transparent. Color code: As (dark red), Al (light blue), I (purple), C (transparent black). 
using $\mathrm{As}^{0}{ }_{\text {(nano) }}$ new products, which are not accessible by the classic route (decomposition of organoarsenides) were synthesised. Thus, the $\mathrm{As}_{4} \mathrm{Al}_{6}$ cage 1 and the unusual aluminium arsenic $\mathrm{As}_{5} \mathrm{Al}_{7}$ cage 2 were obtained by our new synthetic approach. Furthermore, the dialanes $\left[\mathrm{Cp}^{*} \mathrm{AlX}\right]_{2}(\mathrm{X}=\mathrm{Br}, \mathrm{I})$ were applied as single electron reducing agents for the reduction of

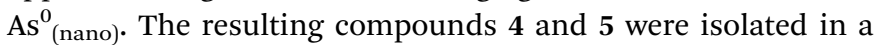
calix-like structural motif in the solid state. In addition, the conversion of $\mathrm{Sb}_{\text {(nano) }}^{0}$ with $\left[\mathrm{AlCp}^{*}\right]_{4}$ confirmed the high reactivity of the nanoparticles by isolating compound 3 . In conclusion, we have successfully broadened the application of group 15 nanoparticles as reactive source for these elements and used them for the first time in main group chemistry.

All authors have given approval to the final version of the manuscript. A. H. synthesized and analysed all compounds with support from L. M., A. H. and L. M. conducted X-ray experiments. PWR originated the idea, supervised the work, and interpreted the results. All authors contributed to the preparation of the manuscript.

We are grateful to the Deutsche Forschungsgemeinschaft (DFG) (No. 266153560, Ro 2008/17-2) for financial support.

\section{Conflicts of interest}

There are no conflicts to declare.

\section{Notes and references}

1 (a) C. Dohmeier, C. Robl, M. Tacke and H. Schnöckel, Angew. Chem., Int. Ed. Engl., 1991, 30, 564-565; (b) S. Schulz, H. W. Roesky, H. J. Koch, G. M. Sheldrick, D. Stalke and A. Kuhn, Angew. Chem., Int. Ed. Engl., 1993, 32, 1729-1731; (c) C. Cui, H. W. Roesky, H.-G. Schmidt, M. Noltemeyer, H. Hao and F. Cimpoesu, Angew. Chem., Int. Ed., 2000, 39, 4274-4276.

2 (a) J. Gauss, U. Schneider, R. Ahlrichs, C. Dohmeier and H. Schnoeckel, J. Am. Chem. Soc., 1993, 115, 2402-2408; (b) C. Dohmeier, H. Krautscheid and H. Schnöckel, Angew. Chem., Int. Ed. Engl., 1995, 33, 2482-2483; (c) C. Dohmeier, D. Loos and H. Schnöckel, Angew. Chem., Int. Ed. Engl., 1996, 35, 129-149; (d) A. Purath, C. Dohmeier, A. Ecker, H. Schnöckel, K. Amelunxen, T. Passler and N. Wiberg, Organometallics, 1998, 17, 1894-1896; (e) C. Schnitter, H. W. Roesky, C. Röpken, R. Herbst-Irmer, H.-G. Schmidt and M. Noltemeyer, Angew. Chem., Int. Ed., 1998, 37, 1952-1955; $(f)$ H. Sitzmann, M. F. Lappert, C. Dohmeier, C. Üffing and H. Schnöckel, J. Organomet. Chem., 1998, 561, 203-208; $(g)$ A. Purath, R. Köppe and H. Schnöckel, Angew. Chem., Int. Ed., 1999, 38, 2926-2928; (h) M. Schormann, K. S. Klimek, H. Hatop, S. P. Varkey, H. W. Roesky, C. Lehmann, C. Röpken, R. Herbst-Irmer and M. Noltemeyer, J. Solid State Chem., 2001, 162, 225-236; $(i)$ H. W. Roesky and S. S. Kumar, Chem. Commun., 2005, 4027-4038.

3 S. Grams, J. Eyselein, J. Langer, C. Färber and S. Harder, Angew. Chem., Int. Ed., 2020, 59, 15982-15986.

4 (a) J. Hicks, P. Vasko, J. M. Goicoechea and S. Aldridge, Nature, 2018, 557, 92-95; (b) J. Hicks, P. Vasko, J. M. Goicoechea and S. Aldridge, J. Am. Chem. Soc., 2019, 141, 11000-11003; (c) R. J. Schwamm, M. D. Anker, M. Lein and M. P. Coles, Angew. Chem., Int. Ed., 2019, 58, 1489-1493; (d) R. J. Schwamm, M. P. Coles, M. S. Hill,
M. F. Mahon, C. L. McMullin, N. A. Rajabi and A. S. S. Wilson, Angew. Chem., Int. Ed., 2020, 59, 3928-3932; (e) S. Kurumada, S. Takamori and M. Yamashita, Nat. Chem., 2020, 12, 36-39; (f) K. Koshino and R. Kinjo, J. Am. Chem. Soc., 2020, 142, 9057-9062.

5 (a) K. Hobson, C. J. Carmalt and C. Bakewell, Chem. Sci., 2020, 11, 6942-6956; (b) J. Hicks, P. Vasko, J. M. Goicoechea and S. Aldridge, Angew. Chem., Int. Ed., 2021, 60, 1702-1713; (c) A. Hofmann, T. Tröster, T. Kupfer and H. Braunschweig, Chem. Sci., 2019, 10, 3421-3428; (d) P. Bag, C. Weetman and S. Inoue, Angew. Chem., Int. Ed., 2018, 57, 14394-14413; (e) R. Yadav, T. Simler, B. Goswami, C. Schoo, R. Köppe, S. Dey and P. W. Roesky, Angew. Chem., Int. Ed., 2020, 59, 9443-9447.

6 (a) W. Uhl, Angew. Chem., Int. Ed. Engl., 1993, 32, 1386-1397; (b) N. Wiberg, K. Amelunxen, T. Blank, H. Nöth and J. Knizek, Organometallics, 1998, 17, 5431-5433; (c) R. J. Wright, A. D. Phillips and P. P. Power, J. Am. Chem. Soc., 2003, 125, 10784-10785; (d) C. Cui, X. Li, C. Wang, J. Zhang, J. Cheng and X. Zhu, Angew. Chem., Int. Ed., 2006, 45, 2245-2247; (e) T. Agou, K. Nagata, T. Sasamori and N. Tokitoh, Phosphorus, Sulfur Silicon Relat. Elem., 2016, 191, 588-590.

7 (a) S. G. Minasian and J. Arnold, Chem. Commun., 2008, 4043-4045; (b) A. Hofmann, A. Lamprecht, O. F. González-Belman, R. D. Dewhurst, J. O. C. Jiménez-Halla, S. Kachel and H. Braunschweig, Chem. Commun., 2018, 54, 1639-1642; (c) A. Hofmann, A. Lamprecht, J. O. C. Jiménez-Halla, T. Tröster, R. D. Dewhurst, C. Lenczyk and H. Braunschweig, Chem. - Eur. J., 2018, 24, 11795-11802.

8 (a) H. W. Roesky, Inorg. Chem., 2004, 43, 7284-7293; (b) T. Chu and G. I. Nikonov, Chem. Rev., 2018, 118, 3608-3680; (c) S. J. Urwin, G. S. Nichol and M. J. Cowley, Chem. Commun., 2018, 54, 378-380; (d) V. Nesterov, D. Reiter, P. Bag, P. Frisch, R. Holzner, A. Porzelt and S. Inoue, Chem. Rev., 2018, 118, 9678-9842.

9 S. Schulz, H. W. Roesky, H. J. Koch, G. M. Sheldrick, D. Stalke and A. Kuhn, Angew. Chem., Int. Ed. Engl., 1993, 32, 1729-1731.

10 A. C. Stelzer, P. Hrobárik, T. Braun, M. Kaupp and B. Braun-Cula, Inorg. Chem., 2016, 55, 4915-4923.

11 C. Dohmeier, H. Schnöckel, C. Robl, U. Schneider and R. Ahlrichs, Angew. Chem., Int. Ed. Engl., 1994, 33, 199-200.

12 (a) S. Schulz, T. Schoop, H. W. Roesky, L. Häming, A. Steiner and R. Herbst-Irmer, Angew. Chem., Int. Ed. Engl., 1995, 34, 919-920; (b) C. K. F. von Hänisch, C. Üffing, M. A. Junker, A. Ecker, B. O. Kneisel and H. Schnöckel, Angew. Chem., Int. Ed. Engl., 1996, 35, 2875-2877; (c) C. Ganesamoorthy, J. Krüger, E. Glöckler, C. Helling, L. John, W. Frank, C. Wölper and S. Schulz, Inorg. Chem., 2018, 57, 9495-9503.

13 (a) C. Schoo, S. Bestgen, A. Egeberg, S. Klementyeva, C. Feldmann, S. N. Konchenko and P. W. Roesky, Angew. Chem., Int. Ed., 2018, 57, 5912-5916; (b) C. Schoo, S. Bestgen, A. Egeberg, J. Seibert, S. N. Konchenko, C. Feldmann and P. W. Roesky, Angew. Chem., Int. Ed., 2019, 58, 4386-4389.

14 C. Schöttle, P. Bockstaller, R. Popescu, D. Gerthsen and C. Feldmann, Angew. Chem., Int. Ed., 2015, 54, 9866-9870.

15 (a) A. F. Hollemann and E. Wiberg, Inorganic chemistry, Walter de Gruyter, Berlin, 102 edn, 2007; $(b)$ M. Seidl, G. Balázs and M. Scheer, Chem. Rev., 2019, 119, 8406-8434.

16 C. K. F. von Hänisch, C. Üffing, M. A. Junker, A. Ecker, B. O. Kneisel and H. Schnöckel, Angew. Chem., Int. Ed. Engl., 1996, 35, 2875-2877.

17 R. J. Wehmschulte and P. P. Power, J. Am. Chem. Soc., 1996, 118, 791-797.

18 R. L. Wells, A. T. McPhail and T. M. Speer, Organometallics, 1992, 11, 960-963.

19 F. Lu, X. Li, Z. Sun, Y. Zeng and L. Meng, Dalton Trans., 2015, 44, 14092-14100.

20 D. D. Eley, J. H. Taylor and S. C. Wallwork, J. Chem. Soc., 1961, 3867-3873.

21 A. Bondi, J. Phys. Chem., 1964, 68, 441-451. 